\title{
Formulation of an anti-inflammatory drug as fast dissolving tablets
}

\author{
Magdy Ibrahim Mohamed ${ }^{1}$, Boushra Mohammed El-Houssieny ${ }^{2}$, Maram \\ Mourad Mansour $^{2}$ M. I. Mohamed ${ }^{1}$, B. M. El-Houssieny ${ }^{2}$ and M. M. Mansour ${ }^{2}$ \\ ${ }^{I}$ Professor of pharmaceutics and industrial pharmacy - Pharmaceutics department, Collage of Pharmacy, \\ Cairo University. \\ ${ }^{2}$ Professor of pharmaceutics -ex-head of pharmaceutics department, National Organization for Drug Control \\ and Research. \\ ${ }^{2}$ Assistant lecturer of pharmaceutics-Pharmaceutics department, National Organization for Drug Control and \\ Research.
}

\begin{abstract}
The demand for mouth dissolving tablets has been growing during the last decade especially for elderly and children who have difficulties in swallowing. Ketorolac tromethamine is an effective antiinflammatory agent that has been extensively used for the prevention of pain and inflammation associated with a wide variety of reasons. This study was aimed to form Ketorolac tromethamine mouth dissolving tablets by direct compression using superdisintegratants as crospovidone $(C P)$,crosscarmellose sodium (CCS), and sodium starch glycolate (SSG) at concentrations of 3\%, 6\%, 9\%, and $12 \%$. The physical mixtures of the drug and the used excipients were evaluated for their micromeretric properties such as angle of repose, particle size, Hausner's ratio and \% compressibility. Also, FTIR spectroscopy and DSC calorimetry were performed to indicate any possible interaction between the drug with the used excipients. All the prepared tablets were evaluated for their weight variation, thickness, hardness, wetting time, and disintegration time. Also in-vitro release study was done for all the prepared tablets using distilled deionized water as dissolution medium at $37.5 \pm 0.5 c^{\circ}$. Based on in-vitro release study and stability studies, G5 (contained 3\% CCS) was found to be the promising formulae and subjected to further studies.
\end{abstract}

Key words: Fast dissolving tablets, Ketorolac tromethamine, Crospovidone, and Crosscarmellose.

\section{Introduction}

Many patients express difficulty in swallowing tablets and hard gelatin capsules, resulting in noncompliance and ineffective therapy ${ }^{(1)}$. Thus difficulty is particularly experienced by pediatric and geriatric patients. Different approaches are used for development of fast dissolving tablets such as using superdisintegrants namely croscarmellose sodium,crospovidone and sodium starch glycolate. Another approach, maximaizes the porous structure of tablet by sublimation method.Vacuum drying has been used to form porous structure of tablets ${ }^{(2-3)}$. Ketorolac tromethamine is a non steroidal anti-inflammatory drug commonly used to decrease post operative pain associated with surgical treatment ${ }^{(4)}$ Ketorolac tromethamine is found to be as effective as morphine for postoperative pain in children with fewer side effects ${ }^{(5)}$.

\section{Materials and methods}

2.1. Materials

Ketorolac tromethamine was obtained from Elamrya Pharmacutical Ind-Egypt.All other chemicals of analytical grade were purchased from commercial sources.

2.2Preparation of ketorolac tromethamine tablets ${ }^{(6)}$.

The medicated tablets were prepared by first gentle triturating using mortar The ingredients were weighed and mixed in geometrical order and compressed into tablets of weight $100 \mathrm{mg}$ using $6 \mathrm{~mm}$ round flat punches on 10 station rotary tablet machine( Single punch tablet press Erweka type-Germany ). A batch of 100 tablets of each formulation was prepared for all the designed formulations. The dose of ketorolac tromethamine was $10 \mathrm{mg}$, in each tablet.

2.3. Micromeretic properties of physical mixtures of ketorolac tromethamine with different excipients used.

2.3.1.Bulk density $\left(D_{b}\right){ }^{(7)}$.

It is the ratio between a mass of granules and the bulk volume .It is expressed by $\mathrm{gm} / \mathrm{ml}$

Bulk density $=$ weight of granules/ Bulk volume 


$$
\mathrm{D}_{\mathrm{b}}=\mathrm{M} / \mathrm{V}_{0}
$$

Where $\mathrm{M}$ is the mass of the powder, and $\mathrm{V}_{0}$ is bulk volume

\subsubsection{Tapped density $\left(D_{t}\right)^{\left({ }^{(8-9)}\right.}$.}

It is the ratio of total mass of powder to the tapped volume of the powder. It can be calculated from the following equation and expressed also in $\mathrm{g} / \mathrm{ml}$. It is determined by transferring the weighed amount of the blend $5 \mathrm{gm}$ to the graduated cylinder $(10 \mathrm{ml})$ with the aid of a funnel. The blend is tapped for a fixed time, the tapped volume $\left(\mathrm{V}_{t}\right)$ is recorded

$$
\mathrm{D}_{\mathrm{t}}=\mathrm{M} / \mathrm{V}_{\mathrm{t}}
$$

Where $\mathrm{M}$ is the mass of the powder and $\mathrm{V}_{\mathrm{t}}$ is the tapped volume of the powder.

\subsubsection{Angle of repose ( $\theta)^{(10)}$}

The friction forces in a loose powder can be measured by the angle of repose. It is defined as maximum angle possible between the surface of the pile of powder and horizontal plane. The powder is allowed to flow freely through a cut stem funnel which height was adjusted in such a way that the tip of the funnel just touched the apex of the heap of the powder. The diameter of the powder cone is measured and its angle of repose can be calculated using following equation :

$$
\begin{gathered}
\tan (\theta)=h / r \\
(\theta)=\tan ^{-1}(\mathrm{~h} / \mathrm{r})
\end{gathered}
$$

Where $(\theta)$ is the angle of repose, $h$ is the height in $\mathrm{cms}$ and $\mathrm{r}$ is the radius in $\mathrm{cms}$

\subsection{4.. Compressibility Index (Carr's Index) and Hausner's ratio ${ }^{(11)}$ :}

The compressibility index (Carr's Index) and Hausner's ratio of all the prepared powder blends were determined from their bulk density and tapped density values as follows:

Compressibility index $(\%)=[$ (Tapped density-Bulk density $) \times 100]$

Hausner's ratio $=$ Tapped density/ Bulk density

Tapped density

\subsubsection{Particle size determination}

The particle size study was performed to ensure homogeneity and uniformity of each drug-excipient blend. The particle size of all the prepared powder blends was recorded using Horiba Laser scattering particle size distribution analyzer- model LA-920. Japan.

\subsection{Evaluation of ketorolac tromethamine fast dissolving tablets \\ 2.4.1. Weight variation}

The individual weights of twenty tablets selected randomly from each formulation were reported and the average weight and standard deviations were calculated ${ }^{(12)}$.

\subsubsection{Tablet hardness}

Six accidentally selected tablets from each formulation were tested for tablet hardness measurement using Erweka hardness tester -Heusenstamm- Gernany. The results were calculated as the mean hardness in $(\mathrm{Kp})^{(13-14)}$.

\subsubsection{Content uniformity ${ }^{(15)}$.}

Ten tablets were randomly selected from each formulation and pulverized to a fine powder. A quantity of powder equivalent to a single dose was weighed and assayed for the drug content using a UV visible spectrophotometer (Shimadzu model UV-2450-Japan) at wavelength $322 \mathrm{~nm}$.

\subsubsection{Tablet friability}

Pre-weighed sample of tablets (six tablets from each batch) was placed in the drum of the friabilator (Erweka type, GmbH-Germany), and rotated for 100 revolutions ( $25 \mathrm{rpm}$ for $4 \mathrm{~min}$ ). Tablets were dusted and reweighed. The percent loss in the weight was calculated and, taken as a measure of friability ${ }^{(16-17)}$. The friability $\%$ was calculated from the following equation ${ }^{(18-19)}$ :

$\%$ Friability $=[$ (Initial weight of tablets- final weight of tablets $) \times 100]$ initial weight of tablets 


\subsubsection{In vitro disintegration time ${ }^{(21)}$}

It was determined using disintegration test apparatus ( Pharmatest type,PTZ3-West Germany). A tablet was placed in each of six tubes of the apparatus and one disc was added to each tube. The time in seconds taken for complete disintegration of the tablet was recorded.

\subsubsection{Wetting time ${ }^{(21)}$.}

Twice folded tissue papers were placed in a petri dish of $5 \mathrm{~cm}$ diameter. Six $\mathrm{ml}$ of water were added to the petri dish. A tablet was carefully placed on the surface of the tissue paper.The time required for water to reach the upper surface of the tablet and to completely wet it was noted as the wetting time.

\subsubsection{In-vitro release of the prepared fast dissolving ketorolac tromethamine tablets}

The release study of ketorolac tromethamine from the prepared tablets was carried out using USP standard dissolution apparatus II ( Hanson Research, SR8 plus- USA) containing $500 \mathrm{ml}$ of distilled deionized water as a dissolution medium ( Paddle method). Sample $(5 \mathrm{ml}$ ) were collected at predetermined time intervals $(1,2,3,4,5,6,7,8,9,10 \mathrm{~min})$ and replaced with equal volume of fresh medium, filtered through $0.45 \mu \mathrm{m}$ membrane filter disc, and analyzed with a UV visible spectrophotometer (Shimadzu model UV-2450) at $\lambda_{\max } 322$.

\subsection{Investigation of physicochemical compatibility of the used excipients with the drug 2.5.1. Differential scanning calorimetry (DSC)}

The thermal behavior of the selected formulae G2, G5, G9 and pure ketorolac tromethaine drug was investigated using differential scanning calorimeter (Shimadzu-DSC-50. Japan). The instrument was first calibrated with purified indium (99.99\%). Samples of (2-4 mg) of each formula as well as the pure drug were heated under nitrogen atmosphere as a carrier gas on an aluminium pan at a flow rate of $25 \mathrm{ml} / \mathrm{min}$ and a heating rate of $10^{\circ} \mathrm{C} / \mathrm{min}$ over a temperature range of $20-400^{\circ} \mathrm{C}$.

\subsubsection{Fourier transform infra red spectroscopy (FTIR)}

Infrared spectra of all the prepared formulae and pure ketorolac tromethamine were recorded using Fourier transform IR spectrophotometer ( Shimadzu, IR-435, U-04- Japan).

\section{Stability study}

Fast dissolving tablets of formulae G2, G5, and G9 were stored in well-closed amber glass vials at ambient conditions (on the shelf) for 12 months and under accelerated conditions of a temperature of $40{ }^{\circ} \mathrm{C}$ and $75 \%$ relative humidity for three months ${ }^{(22-23)}$. The tablets were visually inspected for any physical changes and their friability, disintegration time and dissolution behaviors were compared before and after storage.

\section{Results and discussions}

Micromeretic properties of physical mixtures of ketorolac tromethamine with different excipients .

In the present study, twelve ketorolac tomethamine fast dissolving tablets were prepared by direct compression method as shown in table (1). Croscarmellose sodiume, crospovidone and sodium starch glycolate were used as superdisintegrants in four different concentrations (3\%, 6\%,9\% and $12 \%)$. Avicel ${ }^{\circledR}$ PH102 was used as a binder due to its excellent compatibility at low pressures and high dilution potential, being also chemically inert and compatible with most drugs ${ }^{(24-25)}$. Micromeretic properties of the prepared physical mixtures of ketorolac tromethamine showed good compressibility and flowability behavior as indicated from their compressibility index, angle of repose and Hausner's ratio. These results were in agreement with standard requirements of USP as shown in table (2). Also, uniformity of particle size of the drug-excipient blends signified good homogeneity and uniformity during mixing and granulation processes as shown in figure (1).

All the prepared tablets had acceptable hardness in the range from $(3.133 \pm 0.404 \mathrm{Kp})$ to $(5.967 \pm 0.764$ $\mathrm{Kp}$ ) as graphically represented in figure (2). All the prepared tablets are with acceptable friability less than $1 \%$ as shown in figure (3). Tablets prepared with the superdisintegrant croscarmellose sodium had the shortest disintegration and wetting times followed by those prepared with crospovidone and finally those prepared with sodium starch glycolate which had the longest disintegration and wetting times as illustrated graphically in figures $(4 \& 5)$.

The release of the drug from the prepared fast dissolving tablets was better than that from the conventional commercial tablets Fam ${ }^{\circledR}$ as shown in figures (6-8). All the prepared tablets with different superdisintegrantes showed $75 \%$ release of the drug within the first 5 minutes while only $27.474 \%$ of the drug was released from commercial tablets. Formulae G2, and G5 released $100 \%$ of the drug within 4 and 3 minutes respectively. Increasing the concentration of crospovidone as a superdisintegrant had no significant effect on the dissolution profile of the tablets On the other hand, the change in concentration of both the superdisintegrants sodium starch glycolate and croscarmellose sodium had significant effect on the dissolution profile of their 
tablets. The selected excipients used, mannitol and Avicel PH 102, had a great effect on enhancing dissolution of the drug from the prepared tablets.

The physical mixtures of ketorolac tromethamine with the different used excipients of the selected tablet formulae (G2, G5 and G9) showed no physical or chemical interactions as detected from their DSC thermograms, and FTIR spectra, shown in figures $(9 \& 10)$.

The stability studies showed a significant change in the dissolution profile of the drug from the tablets of formulae G2, and G9 when stored under both ambient and accelerated conditions as shown in figures (11 \& 12). Therefore, Tablets of formula G5 (containing 3\% corscarmellose sodium as superdisintegrant, $30 \%$ Avicel PH102, 5\% aspartame , 1\% talc , 1\% magnesium stearate, and mannitol Q.S.) could be considered as the best selected formulation to prepare KT fast dissolving tablets, since they showed no significant change in the dissolution profile and its physicochemical characters upon storage under both ambient and accelerated conditions.

\section{References}

[1]. Change RK, Guo X, Burnsidw B, et al. Fast dissolving tablets. Pharm. Technol.2000: 52-58

[2]. Goel H, Rai P, Rana V, et al .Orally disintegrating systems: Innovations in formulation and technology. Recent Patent on Drug Delivery \& Formulation. 2008: 258-274.

[3]. Reddy LH, Ghose B. Fast dissolving drug delivery systems: A review of the literature. Indian J. Pharm.Sci. 2002: 331-336 .

[4]. Gicil M, Wilkes RN, Terri B.American cancer society consumer guide to cancer drugs. $2^{\text {nd }}$ ed. Jones and Bartlett Publishers, Canada. 2004; p 410.

[5]. MC Guire DB, Yarbaro HC, and Ferrill BR. Cancer pain management. 2nd ed. Jones and Bartlett Publishers, UK. 1995; $\mathrm{p} 94$.

[6]. Patil SB, Rao DK, Kulkarni U, et al. Formulation and evaluation of fast dissolving tablets of granisetron hydrochloride by direct compression technique.Int.J. Curr. Pharma. Res.2011: 124- 128 .

[7]. Tiwari V, Kinikar DJ, Pillai K, et al. Preparation and evaluation of fast dissolving tablets of celecoxibe. J. Curr. Pharm. Resc.2010: 4-10 .

[8]. -Shah D, Shah Y, and Rampradhan M. Development and evaluation of controlled release diltiazim hydrochloride microparticles using cross-linked polyvinyl alchol.Drug dev.Ind.Pharm.1977: 567-574.

[9]. Raju SR, ShanmuganathanS, Sekharan RT, et al. Formulation and evaluation of mouth dissolving famotidine tablets. IJCRGG.2009: 1251-1256.

[10]. Govedrica B, Injac R, Dreu R, and Srcic S. Formulation and evaluation of immediate release tablets with different types of paracetamol powders prepared by direct compression. African . J.Pharm. Pharmaco.2011: 31-41.

[11]. - Britich Pharmacopeia, H.M.Satationer office, London. 2009; p 735.

[12]. Indhumathi D. Formualtion and evaluation of orodissolving tablet of fluoxetine using superdisintegrants.Int.J.Pharma.Bio Sci. 2011: 833-847

[13]. Lachman L, and Lieber HA. Pharmaceutical dosage forms of tablets. Vol II. Marcel Dekker, Inc , New York. 1981 ; pp $241-243$.

[14]. - Gaur K, Tyagi LK, Kori ML, et al. Formulation and characterization of fast disintegrating tablet of aceclofenac by using sublimation method.Int. J. Pharma. Sci. Drug Res. 2011: 19-22 .

[15]. Nagendrakumar D, Raju S A, Shirsand S B, et al . Design of fast dissolving granisetron HCL tablets using novel co-processed superdisintegrants.J.Biosci Tech.2009: 8-14.

[16]. Liberman HA, and Kanig JI. The theory and practice of industrial pharmacy. $3^{\text {rd }}$ ed. Lee and Febiger, Philadelphia.P.A. 1986;P 294

[17]. United state pharmacopeial convention, National formulary 22: Pharmacy compounding practice in the United States Pharmacopia. 27/ Rockvilee, Md 20852. 2004; p1700.

[18]. Lachman L, Lieberman A, and Kinig JL.The theory and practice of industrial pharmacy. Varghese Publishing House, Bombay. 1991; pp 67-68.

[19]. Bhardwaj V, Bansal M, and Sharma P K. Formulation and evaluation of fast dissolving tablets of amlodipine besylate using different superdidintegrants and camphor as subliming agent. American-Eurasian.J.Sci Res.2010: 264-269

[20]. Kumar R, Patil S, Patil MB, et al. Paschapur, M.S.: Formulation evaluation of mouth dissolving tablets of fenofibrate using sublimation technique.Int.J.Chem Tech Res. 2009: 840-850.

[21]. Chacko AJ, Jose S, Babu N, et al . Design and development of orodispersible tablets of promethazine theoclate using coprocessed superdidintegrants and subliming materials.Int.J.Innovative Pharma Res. 2010 : 53-56 .

[22]. Nagendra KD, Raju S.A, and Shirsand SB. Formulation design of fast dissolving tablets of fexofenadine hydrochloride by sublimation method. Int. J. Pharma. Bio Sci. 2010: 1-7.

[23]. Noushin B, Naghmeh H, Seyed M.F, et al .Development and optimization of sublingual tablet formulation for physostigmine salicyate.Acta Pharm. 2009: 301-312.

[24]. Jivard M, Martini LG, and Thompson CM. An overview of the different excipients useful for the direct compression of tablets. Pharm.Sci.Technol. 2000: 58-63.

[25]. Bastos OM, Friedrich RB,and Beck RCR. Effects of filler-binders and lubricants on physicochemical properties of tablets obtained by direct compression: A 22 factorial design.Lat.Am.J.Pharm.2008: 578-583. 
Formulation of an anti-inflammatory drug as fast dissolving tablets

Table (1): (\%) Composition of ketorolac tromethamine fast dissolving tablets prepared by direct

\begin{tabular}{|c|c|c|c|c|c|c|c|c|c|c|c|c|}
\hline \multirow[t]{2}{*}{ Components } & \multicolumn{12}{|c|}{ Formula code } \\
\hline & G1 & G2 & G3 & G4 & G5 & G6 & G7 & G8 & G9 & G10 & $\begin{array}{c}\text { G1 } \\
1\end{array}$ & $\begin{array}{c}\text { G1 } \\
2\end{array}$ \\
\hline $\begin{array}{c}\text { Ketorolac } \\
\text { tromethamine }(\mathrm{KT})\end{array}$ & 10 & 10 & 10 & 10 & 10 & 10 & 10 & 10 & 10 & 10 & 10 & 10 \\
\hline Crospovidone ( CP ) & 3 & 6 & 9 & 12 & - & - & - & - & - & - & - & - \\
\hline $\begin{array}{c}\text { Croscarmellose sodium } \\
\text { (CCS) }\end{array}$ & - & - & - & - & 3 & 6 & 9 & 12 & - & - & - & - \\
\hline $\begin{array}{l}\text { Sodium starch } \\
\text { glycolate (SSG) }\end{array}$ & - & - & - & - & - & - & - & - & 3 & 6 & 9 & 12 \\
\hline Avicel® PH ( 102 ) & 30 & 30 & 30 & 30 & 30 & 30 & 30 & 30 & 30 & 30 & 30 & 30 \\
\hline Mannitol & 50 & 47 & 44 & 41 & 50 & 47 & 44 & 41 & 50 & 47 & 44 & 41 \\
\hline Aspartame & 5 & 5 & 5 & 5 & 5 & 5 & 5 & 5 & 5 & 5 & 5 & 5 \\
\hline Magnesium stearate & 1 & 1 & 1 & 1 & 1 & 1 & 1 & 1 & 1 & 1 & 1 & 1 \\
\hline Talc & 1 & 1 & 1 & 1 & 1 & 1 & 1 & 1 & 1 & 1 & 1 & 1 \\
\hline Total ( mg) & 100 & 100 & 100 & 100 & 100 & 100 & 100 & 100 & 100 & 100 & 100 & 100 \\
\hline
\end{tabular}

compression method.

Table (2): Micromeretics properties of the prepared physical mixtures of ketorolac tromethamine with different used excipients

\begin{tabular}{|c|c|c|c|c|c|c|}
\hline $\begin{array}{c}\text { Formulation } \\
\text { Code }\end{array}$ & $\begin{array}{c}\text { Angle of repose } \\
\text { ( } \theta \text { ) }\end{array}$ & $\begin{array}{c}\text { Bulk density } \\
(\mathrm{g} / \mathrm{ml})\end{array}$ & $\begin{array}{c}\text { Tapped density } \\
(\mathrm{g} / \mathrm{ml})\end{array}$ & $\begin{array}{l}\text { Compressibility } \\
\text { index } \\
(\%)\end{array}$ & Hausner's ratio & $\begin{array}{c}\text { Particle size } \\
(\mu \mathrm{m})\end{array}$ \\
\hline G1 & $22.5^{\circ}$ & 0.370 & 0.417 & 12.5 & 1.125 & 0.299 \\
\hline G2 & $16.875^{\circ}$ & 0.333 & 0.385 & 15.38 & 1.154 & 0.295 \\
\hline G3 & $15.882^{\circ}$ & 0.333 & 0.385 & 15.38 & 1.154 & 0.285 \\
\hline G4 & $18^{\circ}$ & 0.294 & 0.345 & 17.24 & 1.172 & 0.274 \\
\hline G5 & $20.76^{\circ}$ & 0.313 & 0.357 & 14.285 & 1.143 & 0.331 \\
\hline G6 & $15.882^{\circ}$ & 0.303 & 0.351 & 17.84 & 1.178 & 0.354 \\
\hline G7 & $16.8^{\circ}$ & 0.333 & 0.385 & 15.384 & 1.154 & 0.330 \\
\hline G8 & $15^{\circ}$ & 0.303 & 0.345 & 13.79 & 1.138 & 0.374 \\
\hline G9 & $20.907^{\circ}$ & 0.294 & 0.333 & 13.265 & 1.133 & 0.274 \\
\hline G10 & $26.629^{\circ}$ & 0.313 & 0.360 & 15.016 & 1.150 & 0.243 \\
\hline G11 & $24.224^{\circ}$ & 0.333 & 0.385 & 15.616 & 1.156 & 0.234 \\
\hline G12 & $25.833^{\circ}$ & 0.476 & 0.556 & 16.807 & 1.168 & 0.242 \\
\hline
\end{tabular}

Table (3): Pharmaceutical quality control characteristics of ketorolac tromethamine fast dissolving tablets prepared by direct compression

\begin{tabular}{|c|c|c|c|c|c|c|c|c|}
\hline $\begin{array}{l}\text { Formul } \\
\text { a } \\
\text { code }\end{array}$ & $\begin{array}{c}\text { Weight } \\
\text { variation } \\
(\mathrm{mg}) \pm(\mathrm{SD})\end{array}$ & $\begin{array}{l}\text { Thickness } \\
(\mathrm{mm}) \pm \\
\text { (SD) }\end{array}$ & $\begin{array}{l}\text { Diameter } \\
(\mathrm{mm}) \pm(\mathrm{SD})\end{array}$ & $\begin{array}{l}\text { Hardness } \\
(\mathrm{kp}) \pm(\mathrm{SD})\end{array}$ & $\begin{array}{l}\text { Drug content } \\
(\%) \pm(\mathrm{SD})\end{array}$ & $\begin{array}{l}\text { Friability } \\
(\%) \pm(\mathrm{SD})\end{array}$ & $\begin{array}{l}\text { Wetting time } \\
(\mathrm{sec}) \pm(\mathrm{SD})\end{array}$ & $\begin{array}{c}\text { Disintegration } \\
\text { time (sec) } \pm \\
\text { (SD) }\end{array}$ \\
\hline Gl & $\begin{array}{c}98.96 \pm \\
2.169 \\
\end{array}$ & $2.2 \pm 0.07$ & $7.05 \pm 0.026$ & $2.667 \pm 0.896$ & $98.477 \pm 0.136$ & $0.104 \pm 0.005$ & $15.667 \pm 0.577$ & $13.333 \pm 0.577$ \\
\hline G2 & $\begin{array}{c}99.467 \pm 1.18 \\
5\end{array}$ & $\begin{array}{l}2.25 \pm \\
0.0153\end{array}$ & $7.087 \pm 0.095$ & $2.633 \pm 0.306$ & $99.595 \pm 0.082$ & $\begin{array}{c}0.355 \pm \\
0.035\end{array}$ & $25.667 \pm 2.087$ & $23.333 \pm 0.577$ \\
\hline G3 & $\begin{array}{c}100.56 \pm 0.32 \\
1\end{array}$ & $\begin{array}{c}0.0177 \pm \\
0.021\end{array}$ & $7.12 \pm 0.113$ & $2.633 \pm 0.666$ & $98.809 \pm 0.187$ & $0.333 \pm 0.0$ & $\begin{array}{c}30.333 \pm 2 . \\
517\end{array}$ & $28.333 \pm 1.555$ \\
\hline G4 & $100.5 \pm$ & $2.27 \pm 0.01$ & $7.067 \pm 0.029$ & $4.8 \pm 0.3$ & $97.41 \pm 0.169$ & 0.00 & $38 \pm 0$ & $30.667 \pm 1.155$ \\
\hline G5 & $\begin{array}{c}98.377 \pm 0.36 \\
6 \\
\end{array}$ & $\begin{array}{l}2.27 \pm \\
0.006\end{array}$ & $7.057 \pm 0.005$ & $\begin{array}{c}3.133 \pm \\
0.404\end{array}$ & $101.247 \pm 0.206$ & $\begin{array}{c}0.132 \pm \\
0.023\end{array}$ & $13.333 \pm 1.528$ & $10.333 \pm 0.577$ \\
\hline G6 & $99.017 \pm 0.31$ & $2.347 \pm 0$ & $7.057 \pm 0.005$ & $2.067 \pm 0.058$ & $99.294 \pm 0.949$ & 0.00 & $11.333 \pm 1.155$ & $12 \pm 1$ \\
\hline G7 & $\begin{array}{c}99.23 \pm \\
0.325\end{array}$ & $\begin{array}{l}2.23 \pm \\
0.0794\end{array}$ & $7.043 \pm 0.021$ & $4.067 \pm 0.208$ & $98.883 \pm 0.719$ & $\begin{array}{c}0.172 \pm \\
0.025\end{array}$ & $17 \pm 1.73$ & $16.666 \pm 0.577$ \\
\hline G8 & $100 \pm 0.721$ & $2.28 \pm 0.01$ & $7.037 \pm 0.067$ & $2.767 \pm 0.115$ & $100.893 \pm 0.222$ & $\begin{array}{c}0.144 \pm \\
0.019\end{array}$ & $21 \pm 2.645$ & $18.660 \pm 1.527$ \\
\hline G9 & $\begin{array}{c}99.723 \pm \\
0.500\end{array}$ & $\begin{array}{c}2.243 \pm \\
0.021\end{array}$ & $6.803 \pm 0.021$ & $3.133 \pm 0.451$ & $93.407 \pm 0.56$ & $\begin{array}{c}0.178 \pm \\
0.123\end{array}$ & $45.333 \pm 1.528$ & $33.333 \pm 0.577$ \\
\hline Gl0 & $\begin{array}{l}100.38 \pm \\
0.095\end{array}$ & $\begin{array}{l}2.227 \pm \\
0.006\end{array}$ & $6.863 \pm 0.075$ & $2.70 \pm 0.289$ & $97.054 \pm 0.435$ & $\begin{array}{c}0.182 \pm \\
0.009\end{array}$ & $55.333 \pm 2.887$ & $44.667 \pm 2.082$ \\
\hline G11 & $\begin{array}{c}100.1 \pm \\
0.566\end{array}$ & $\begin{array}{c}2.283 \pm \\
0.021\end{array}$ & $6.806 \pm 0.045$ & $\begin{array}{c}2 . .633 \pm \\
0.289\end{array}$ & $97.402 \pm 0.509$ & $\begin{array}{c}0.504 \pm \\
0.028\end{array}$ & $65 \pm 2$ & $53.000 \pm 3$ \\
\hline G12 & $\begin{array}{l}98.733 \pm \\
0.704 \\
\end{array}$ & $\begin{array}{l}2.267 \pm \\
0.012\end{array}$ & $6.823 \pm 0.023$ & $2.467 \pm 0.208$ & $98.495 \pm 0.564$ & $\begin{array}{c}0.916 \pm \\
0.074\end{array}$ & $\begin{array}{c}72.667 \pm \\
3.055\end{array}$ & $64.000 \pm 2$ \\
\hline
\end{tabular}




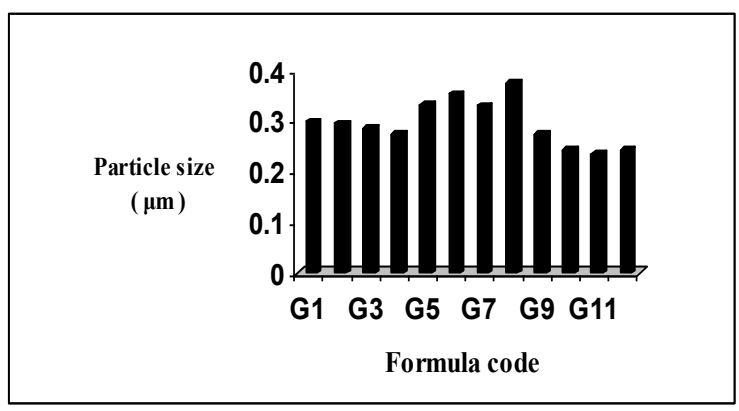

Fig (1): Particle size of the prepared mixtures of ketorolac tromethamine with different used excipients

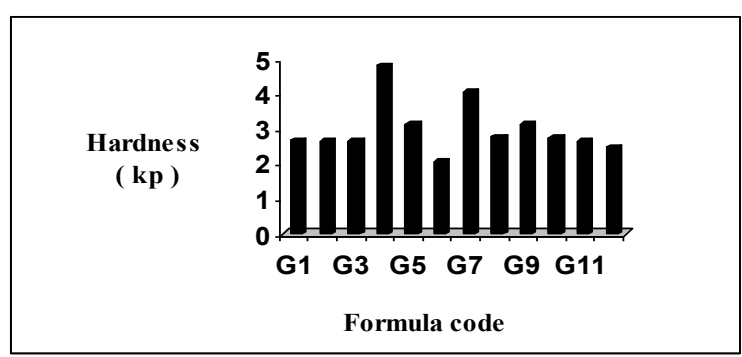

Fig (2): Hardness values of ketorolac tromethamine fast dissolving tablets prepared by direct compression

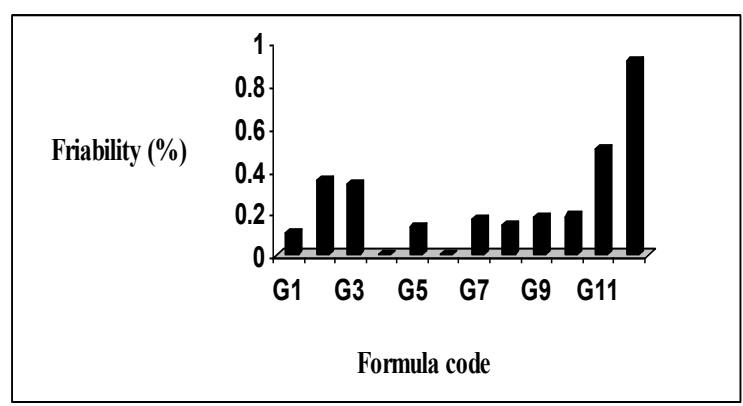

Fig (3): (\%) Friability of ketorolac tromethamine fast dissolving tablets prepared by direct compression

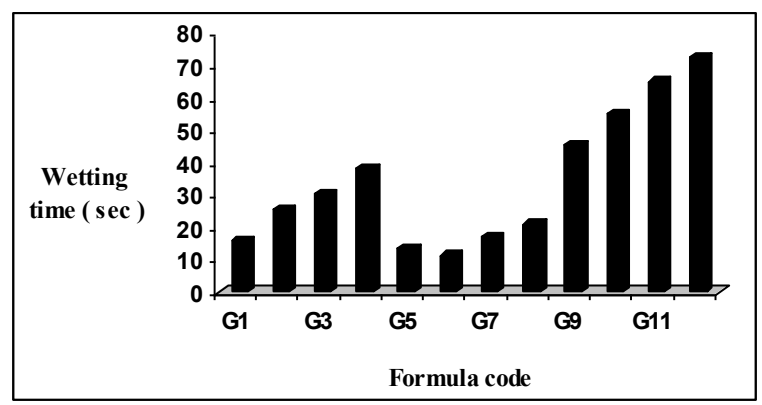

Fig (4): Wetting time of ketorolac tromethamine fast dissolving tablets prepared by direct compression

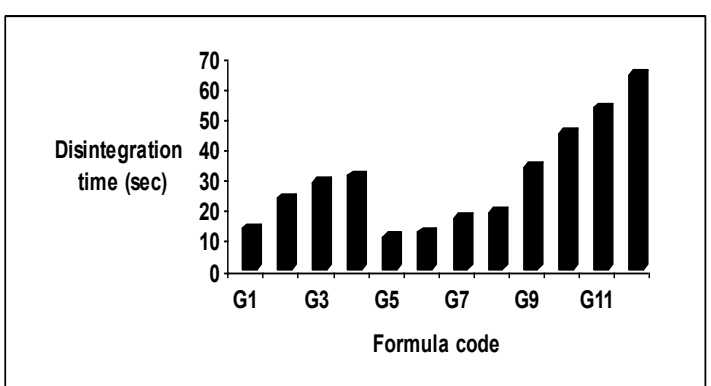

Fig (5): Disintegration time ketorolac tromethaine fast dissolving tablets prepared by direct compression

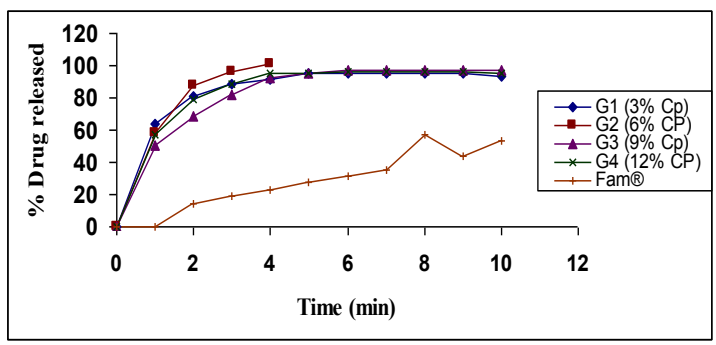

Fig (6): Dissolution profile of commercial tablet Fam ${ }^{\circledR}$ and ketorolac and ketorolac tromethamine fast dissolving tablets prepared with different concentrations of crospovidone

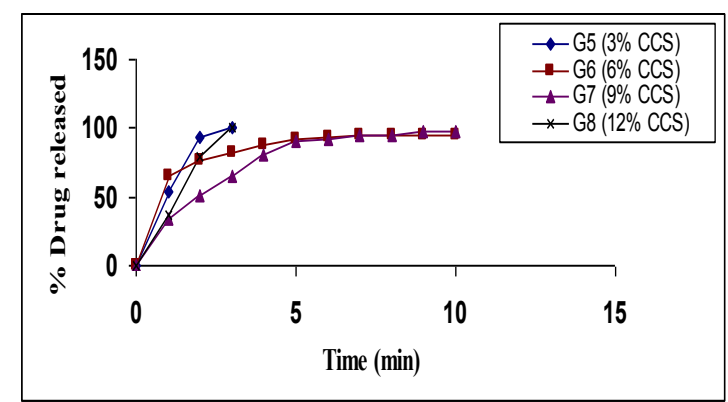

Fig (7): Dissolution profile of ketorolac tromethamine fast dissolving tablets prepared with different concentrations of crosscaramellose

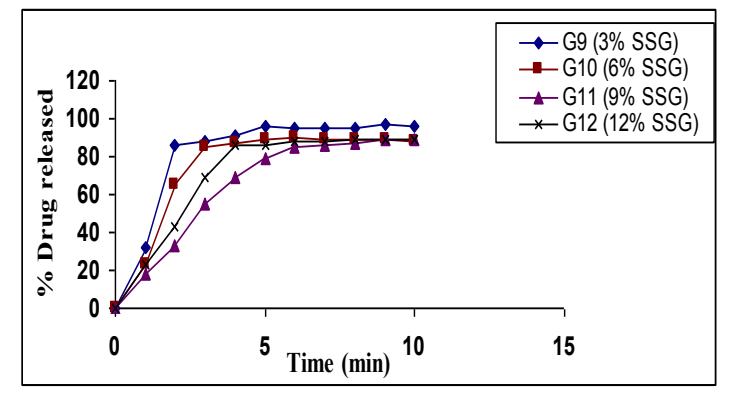

Fig (8): Dissolution profile of ketorlac tromethamine fast tablets prepared with different concentrations of sodium starch glycolate 


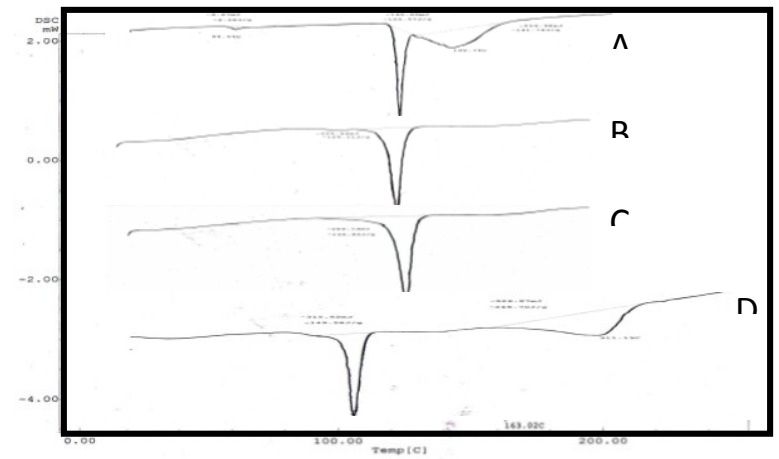

Fig (9): DSC thermograms of pure ketorolac tromethamine (A) and selected fast dissolving tablet formulae (G2, G5, and G9) (B-D), Respectively

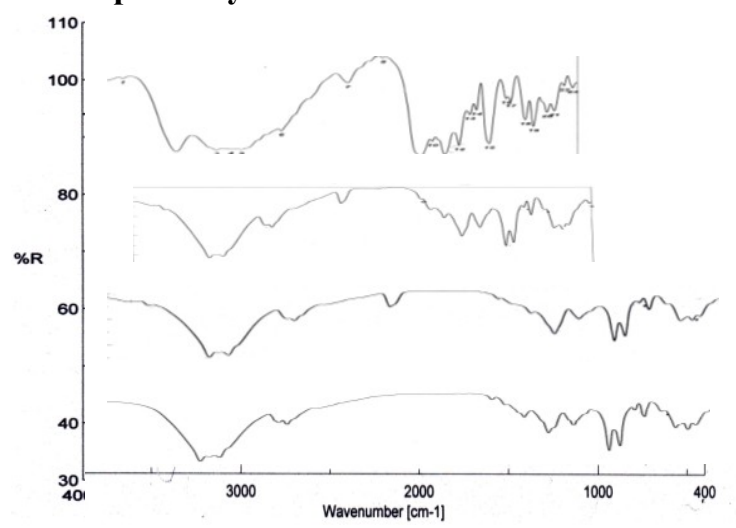

Fig (10) : IR spectra of pure ketorolac tromethamine and selected fast dissolving tablet formulae (G2,G5 and G9) respectively

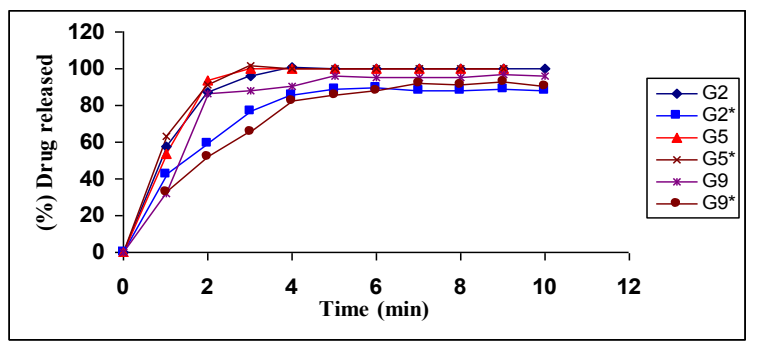

Fig (11): Dissolution profile of fresh and stored selected ketorolac tromethamine fast dissolving tablet of formulae (G2, G5, and G9) after storage at ambient conditions G2, G5, and G9 : Fresh formulae $\mathrm{G} 2 *, \mathrm{G} 5 *$, and G9* : Stored formulae after 12 months

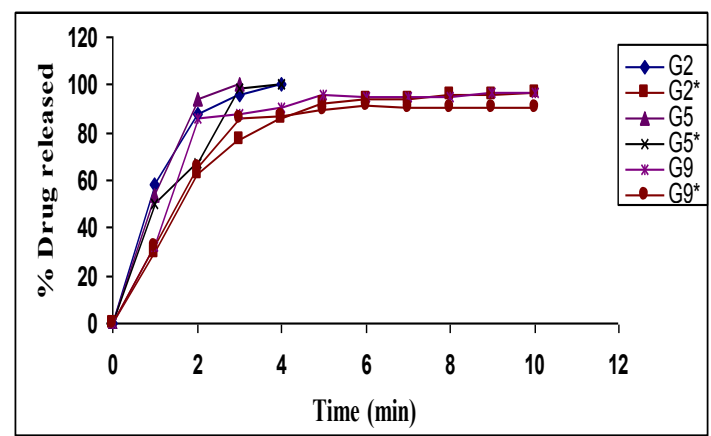

Fig (12): Dissolution profile of fresh and stored selected ketrolac tromethamine fast dissolving tablets of formulae (G2, G5 and G9) after storage under accelerated conditions G2, G5 and G9 : Fresh tablets $\mathrm{G} 2 *, \mathrm{G} 5 *$ and $\mathrm{G}^{*} 9$ : Stored tablets 